Tatjana Jovanović, $\mathrm{PhD}$

Fakulteta za upravo, Univerza v Ljubljani, Slovenia

Tatjana.Jovanovic@fu.uni-lj.si

\title{
EVALUATION OF THE VOLUNTARY TAX COMPLIANCE IN SLOVENIA: TAX AUTHORITY PERSPECTIVE
}

Received: July 17, 2018

Accepted: September 25, 2018

Preliminary communication

\begin{abstract}
Since 2015, certain taxpayers may apply for the special status in order to promote voluntary compliance at the Tax Authority of Republic of Slovenia (FURS), after the horizontal monitoring pilot project was successfully finished in 2010. The theoretical background of the status is based on the idea of co-operative compliance, which can be described as the monitoring, predicting and preventing problems in the tax authority and taxpayers relationship. The purpose of the section is to analyse the instrument, which should establish cooperation based on transparency, understanding and mutual trust between taxpayers and tax authority. The research methodology was focused on survey among tax experts participated in drafting the legislation implementing cooperative relationship as well as experts empowered for monitoring the institute. The main objectives of the study have focused on the current activities identification, the assessment of expectations, the gaps, constraints and potential changes of the instrument identification and the evaluation of the long-term effects of the institute.
\end{abstract}

Keywords: voluntary tax compliance, taxpayer, tax authority, cooperative relationship

JEL: M41

\section{INTRODUCTION}

Tax compliance is crucial for every country, since it is the basic prerequisite for its existence. As a result, the national authorities in charge of collecting tax revenues are forced to manage tax risks, which is a multi-dimensioned activity. These risks primarily stem from the legal environment created by laws, international agreements, and the interpretation of both. As opposed to societies 300 years ago 
that were focused entirely on legality, the legal environment of today strives for a lawful and legitimate authority which in the broadest sense is called good public governance or good administration. It is a more partnership-like, preventive, open, co-operative, responsible, and decentralised public administration, which, however, still strives for the efficiency of authority and society as a whole by virtue of the parallel corrective measures of coercion and coordination (Kovač et al., 2016, p. 20). As regards the attitude of taxpayers to tax compliance, or their conduct in the matter, there have lately been appearing serious doubts in the prevailing economic view that trust is good and control is even better. This long-standing prevailing view argued that deterrence from unlawful conduct is possible through rigid controls or investigations and harsh penalties. However, it has been shown that strict controls and penalties can also have unintended side effects, which is why psychological variables (e.g. attitude to taxation, social norms, the perception of fairness, etc.) are increasingly taken into account. Social control in general and especially investigations as key activities of a regulated society follow the realisation that people observe legal order primarily because it represents the legitimate structure of a regulated society and not out of fear of sanctions and penalties (May and Wood, 2003, p. 117).

On the basis of the above scientific findings, numerous countries have begun introducing "alternative" approaches in the relationship with taxpayers. In addition to the traditional authority - taxpayer relationship founded on hierarchy, we are increasingly seeing co-operative compliance, which can be described as the monitoring, forecasting, and prevention of problems that appear in the relationship between taxpayers and the tax authority. At the same time, the "enhanced relationship" concept began appearing at the level of the Organisation for Economic Co-operation and Development (OECD) and has so far been introduced in several countries while in many more it is still in the development phase.

The aim of the paper is to provide an in-depth analysis of the special status granted for the promotion of voluntary tax compliance, an instrument available to medium-sized and large taxpayers. The Republic of Slovenia enacted it in the autumn of 2015. The main goal of the analysis is to assess the fulfilment of tax authority's expectations when implementing modern tax instrument of voluntary tax compliance. While policy instruments are carriers of causal ideas and economic theories used and adopted by the legislators. Accordingly, effective policy-making and thus tax regulation necessitates effective mechanisms that can facilitate preliminary impact assessment of planned tax instruments. FURS as the leading organization in the legislation preparation and implementation phases has detected numerous positive effects (in particular, encouraging taxpayers to calculate and pay taxes properly and on time, better utilisation of the authority's available human, financial, and material resources) of the observed instrument, 
although no measurable targets or performance criteria of the institute have been set. This fact complicates our research results and their interpretation.

The study was conducted using the methodology of surveying FURS experts who participated in the drafting of legislative bases and those who monitor and implement this institute so as to investigate the current activities of FURS in this field, how the expectations prior to the introduction have been met, what shortcomings, restrictions, or amendments to the present arrangement are necessary and how the long-term effects of this institute have been evaluated.

The paper consists of six sections. The first focuses on the placement of the content in a broader theoretical framework, the second presents the Slovenian model of a co-operative relationship between FURS and taxpayers, while the third presents the results of the analysis conducted among FURS experts. In addition to the conclusions, the fourth section describes the basic starting points for further research and views on the Slovenian model.

\section{MODERN APPROACHES TO TAX COMPLIANCE FROM THE AUTHORITY'S PERSPECTIVE}

Tax compliance represents the extent to which taxpayers comply with tax law. On the other hand, tax non-compliance is defined as the concept of a "tax gap", which represents the difference between actually collected tax revenues and potential tax revenues (James \& Nobes, 2000). A widespread view among tax scholars reveals that the law enforcement is not the reason for paying taxes, while the penalty for ordinary tax convictions is small and the probability of detection is trivial (Andreoni et al., 1998). While compliance and non-compliance is not black and white issue, there are several factors influencing the intensity of compliance, like the degree of tax burden, the purpose of expenditures funded by collected revenues, the form of taxation, the public perception on whether the tax system is fair or not, etc. (Popović, 1997). Numerous studies, economic, legal and psychological, discuss factors that influence the fulfilment of tax liabilities (Posner, 2000, Kirchler et al., 2008, Kirchler et al., Torgler, 2003, 2014, Dimitrijević, 2016). The essay of Posner (2000) focuses on law and social norms of tax compliance, emphasising the aspect of social norms in the society. Kirchler et al., 2008 focused on power of tax authorities and trust in the tax authorities as relevant dimensions for understanding tax compliance. Using the framework as an operational tool, the study has discussed several factors (like fines, audit probabilities, tax rate, knowledge, attitudes, norms and fairness) to find approaches to increase tax compliance. The authors' research has been upgraded by the so-called 'slippery slope' framework as a new approach to understand tax compliance. The slippery slope 
approach supposes two routes to tax compliance: deterrence of tax evasion by audits and fines on the one hand, and building a trusting relationship with taxpayers by services and support on the other hand (Kirchler et al., 2014).

Nowadays tax-related literature emphasizes the meaning of the understanding and cooperation between tax authority and taxpayers in the application of tax legislation. The standpoint of this authority-taxpayers relation is the principle of reciprocity. Positive reciprocity results in the positive attitude of tax authorities towards taxpayers and consequently provides better conditions for voluntary tax compliance. The negative reciprocity may cause legal tax avoidance and tax evasion (Torgler, 2003). Dimitrijević, 2016 develops last 30-years lasting tax literature trend of shaping taxpayers' behaviour starting with self-assessment concept ${ }^{1}$ and spreading it to voluntary tax compliance and cooperative tax compliance as the highest level of this relationship. Generally, economic studies emphasise the so-called external factors, such as non-compliance costs, the likelihood of tax investigation, the amount of the tax base and the tax rate, and penalties, while psychological studies point out the so-called internal factors such as knowledge of tax legislation, the attitude of taxpayers to government and taxation, personal norms, accepted social norms and fairness, tax morality, tax climate, etc. (Hofman et al., 2008).

According to Kirchler et al., 2008, the position the authorities adopt towards taxpayers is important for compliance. The overall tax climate in society can range between antagonistic and synergistic. In an antagonistic climate, taxpayers work against the tax authority and perceive each other as cops and robbers. The tax authority perceives taxpayers as robbers who will avoid payment whenever possible, which is why control is indispensable, while taxpayers feel persecuted and find it acceptable to evade taxes. In a synergistic relationship, however, they work together. The latter is best described using the "service-client relationship" as promoted by the idea of New Public Management. Authorities strive for transparent procedures and respectful and supportive treatment of taxpayers. Such a relationship in society will lead to the voluntary fulfilment of tax liabilities and individuals will be less prone to avoidance and more willing to share the tax burden of society (Kirchler et al., 2008, Braithwaite, 2003).

By far the most prominent model that has combined the economic and psychological knowledge of taxpayers' behaviour is the so-called slippery-slope framework. The latter showed that the power of the tax authority and trust in the authority by taxpayers are the two most important factors affecting tax compliance. It was precisely this scientific conclusion that influenced the practices of tax

The self-assessment concept focuses on the specific trust places by tax authorities in certain categories of taxpayers. 
authorities in managing the behaviour of taxpayers and the practice of inspection. It turned out that repressive authorities have to promote co-operative compliance far more than relying solely on the deterrent effect of inspections and fines. In the vast majority of cases, partnership-like and preventive assurance of compliance with regulations is more effective among taxpayers (Kirchler et al., 2014, Kovač \& Gajduschek, 2015).

The main purpose of improving relations between taxpayers and tax authorities is to increase transparency and co-operation between taxpayers and the tax authority so as to resolve any tax issues in a timely manner. Inclusion in these programmes is typically encouraged by the tax authority, which primarily monitors the scope and quality of the taxpayer's internal tax controls during the inclusion while taking into account tax risks. With their entry into the programme, the taxpayer is expected to reveal the uncertainty of their tax position to the tax authority in return for a timely resolution of any related issues. The concept of "uncertainty of the tax position" represents all the business activities the taxpayer is involved in and for which the taxpayer in a tax procedure seeks to obtain any tax advantages that are not substantiated by a formal tax audit, whereby these tax advantages include anything that reduces the payment of tax. An uncertain tax position can arise from the openness or ambiguity of tax legislation relating to such a position of the taxpayer, especially in terms of the established tax facts, though it may also refer to confusion in calculating the tax base arising from such circumstances affecting the taxpayer. Specifically, it is considered that the tax authority will in this case only audit the submitted tax returns and self-assessment tax returns in order to check any materially undisclosed issues, but not the previously mentioned uncertain tax positions (Simone et al., 2013).

The OECD (2008) identifies three basic mechanisms for improving relations between the tax authority and taxpayers: (1) a unilateral statement by the tax authority setting out the process of improving relations and the consequences if the taxpayer or tax representative agrees to co-operate or not to co-operate; (2) a document signed by the tax authority, taxpayer and tax representative, which determines how they intend to work together and what they intend to do, and with particular focus on the consequences arising if they fail to do so; (3) an agreement between the tax authority and specific taxpayers created to meet specific needs.

In practice, what has become the most prominent is "horizontal monitoring", the model or method where tax authorities and taxpayers sign an agreement. Among the first to adopt this co-operative method was the Dutch administration (tax and customs), with France, South Korea, Australia, and Slovenia setting up a very similar model, which is further discussed below. A somewhat different approach was taken by the United Kingdom and Ireland, as it is not based on the signing of 
formal agreements, but rather on the rules of corporate tax compliance for stable taxpayers (Sertić, 2012, Čičin-Šain, 2016).

\section{DEVELOPING A PARTNERSHIP APPROACH IN THE TAXPAYER - TAX AUTHORITY RELATIONSHIP IN THE REPUBLIC OF SLOVENIA}

In the Republic of Slovenia, the first activities related to the concept of improved relations began in 2010 under the name horizontal monitoring. This is an example of the concept from the third group of the previously mentioned OECD classification and was established in accordance with the 2010-2013 DURS Business Strategy. The Strategy stipulated that the first strategic objective of the then Tax Administration of the Republic of Slovenia (DURS) was to increase voluntary tax compliance. The authority was supposed to achieve this by (Šinkovec, 2012):

- simplifying procedures for taxpayers who want to voluntarily fulfil tax liabilities,

- providing assistance to taxpayers who want to fulfil obligations but are not always able to,

- preventing taxpayers prone to tax avoidance or even evasion from such behaviour by quickly and effectively recognising any such cases,

- applying all enforcement measures provided for by law to those taxpayers who intentionally do not fulfil their tax liabilities.

DURS invited all major companies to participate (721 at the time) and 18 of them did. It was a pioneering attempt at establishing improved, partnership relations between DURS and taxpayers where control was carried out for the current and future activities of taxpayers, but not retroactively, as both sides were used to. The two-year project was followed by a result analysis phase in which interviews with taxpayers were conducted along with a survey among employees. Since both sides evaluated the project positively, the decision was made to continue development of the concept of voluntary compliance or partnership co-operation (Verbič et al., 2014).

The Financial Administration Act (ZFU) adopted at the transformation of DURS into FURS legalised, among other things, the granting of a special status to persons liable for tax in terms of promoting voluntary compliance. It is apparent from the provision of the law that the intention of the authority or the legislator was to establish co-operation for the voluntary fulfilment of tax liabilities and the reduction of the administrative burden of tax control. Taxpayers who wanted or want to obtain this status must meet the following conditions: 
- in the last three years preceding the submission of the application, they obtained unqualified opinions from the auditor who audited the statements in accordance with the Companies Act;

- they have established internal tax controls or, at the time of signing the agreement, they undertake to establish them within the time limit set by FURS which is not longer than two years from the acquisition of the status;

- the taxpayer's management can issue a statement obliging the taxpayer to inform FURS about any circumstances of their business that give (or could give) rise to tax risk, and to provide access to all information related to internal tax controls and take into account all FURS findings and recommendations regarding the adequacy of internal tax controls established;

- the members of the taxpayer's management have not been convicted of a criminal offence by a final decision or an offence concerning regulations on compulsory charges in the period of three years prior to the submission of the application for the special status;

- based on data provided by FURS, it is reasonable to expect that they will fulfil their commitments under the special status for a period of three years prior to the submission of the application for the special status;

- at least three years have elapsed from the time the taxpayer actually started doing business to the time they submitted the application for the special status, whereby the legal predecessor's period of business is taken into account in cases where the person liable for tax was created through a change of status.

The purpose of introducing this institute (Article 99 of ZFU) was to establish co-operation with taxpayers based on transparency, understanding and mutual trust between taxpayers and authorities. As a result of this improved co-operation, the promotion of voluntary compliance, and the reduction of administrative burdens of financial control were expected. The conditions stipulate that taxpayers included in the programme must have internal tax controls, or have to introduce them as soon as possible (two years maximum), thus transferring certain control functions to the taxpayers themselves. However, this does not mean that the taxpayer cannot be subject to a subsequent investigation.

\section{CASE STUDY OF THE STATUS FOR THE PROMOTION OF VOLUNTARY COMPLIANCE}

On the basis of the presented, the main objectives of our study were focusing on FURS' current activities in this field, assessing the fulfilled expectations, identifying possible shortcomings, limits and changes of the current arrangement and 
evaluating the potential long-term effects of the introduction of this institute. The study was undertaken using a survey. The selection of the methodology was adapted to the particularities of the research topic as well as to the special features of FURS as an authority. The individual perception and attitudes as well as organisational policies and practice can be assessed by the survey questionnaires (Baruch and Holtom, 2008). There are three major characteristics of research-oriented surveys, which differentiate them from according surveys as marketing tool or political polls. The purpose as first characteristic of the research-oriented surveys is to produce quantitative descriptions of some aspects of the study population, where the subject might be individuals, groups, organisations, but also projects, applications, etc. Secondly, the structured and predefined questions are a basic way of collecting information, while their answers constitute the data to be analysed. Finally, data is generally collected on the sample of study population in a way to be able to generalise the findings to the population (Pinsonneault and Kraemer, 1993). But, our research has taken into consideration the whole population instead of the sample due to population size. The study was based on a survey carried out among FURS experts who are involved in the instrument of the status for the promotion of voluntary compliance, or were involved in it when the legislation was being adopted at the end of 2016. Considering the fact that this is a relatively new tax institute, we have abandoned the idea of using quantitative research method (interview). After contacting the tax authority's general management, the methodology tools had to be changed. While the interviewing process has not been acceptable for the authority, the survey methodology has been agreed. The survey included 9 open-ended questions (without offering answers). Due to the lack of knowledge of the internal organisational structure and the responsibilities and knowledge of individual experts at FURS, we left the choice of respondents to the authority's management. Initially, we submitted to FURS a survey asking for a minimum of fifteen experts to answer it. After examining the questions, the authority replied to the effect that it can provide only a joint or a uniform answer on three of the questions, while the remaining six questions can be answered by a significantly smaller number of respondents than requested. We received the answers of nine experts with the explanation that this is a very specific topic and very small number of employees has any knowledge about it. From the above it follows that prior to carrying out the survey, the final version of the questionnaire was harmonised with FURS. The survey we sent initially was subsequently adapted to include "general questions for FURS" and a "questionnaire for individual employees". The results of the survey were then analysed in line with the instructions for analysing open-ended questionnaires or structured interviews. The responses of individuals were summarised and presented in Table 1. In addition to the repeated answers that are covered in Table 1, we have presented below those answers that stand out, especially in terms of suggestions, explanations and comments from which we found out even more than we had initially planned. 
Table1: Results of the survey among FURS experts

\begin{tabular}{|c|c|}
\hline Question & Summary of answers \\
\hline $\begin{array}{l}\text { In October } 2015 \text {, the instrument of the "status } \\
\text { for the promotion of voluntary compliance" } \\
\text { was introduced into Slovenian tax legislation. } \\
\text { In your opinion, what were the main purposes } \\
\text { (e.g. improved co-operation with FURS, greater } \\
\text { business transparency, etc.) and objectives (e.g. } \\
\text { expected amount of collected taxes) for the in- } \\
\text { troduction of this instrument? }\end{array}$ & $\begin{array}{l}\text { promoting the voluntary fulfilment of tax liabi- } \\
\text { lities } \\
\text { partnership (transparent business in relation to } \\
\text { FURS and open co-operation) } \\
\text { higher tax revenues } \\
\text { reducing the administrative burdens of FURS in } \\
\text { relation to ex-post financial controls } \\
\text { eliminating the tax risks of financial control }\end{array}$ \\
\hline $\begin{array}{l}\text { How would you evaluate the usefulness of the } \\
\text { pilot approach in introducing legal amendments } \\
\text { in the field of taxation of legal persons in light } \\
\text { of the experience gained from the introducti- } \\
\text { on of the horizontal monitoring instrument, in } \\
\text { particular in terms of planning, implementation } \\
\text { and the subsequent analysis of the pilot results? }\end{array}$ & $\begin{array}{l}\text { good basis for gaining experience } \\
\text { good basis for recording legal matter } \\
\text { very sensible and mutually applicable approach } \\
\text { very useful }\end{array}$ \\
\hline $\begin{array}{l}\text { How do you assess co-operation with compa- } \\
\text { nies - both during the pilot project and at the } \\
\text { present? }\end{array}$ & $\begin{array}{l}\text { good, professional on both sides, in line with } \\
\text { expectations }\end{array}$ \\
\hline $\begin{array}{l}\text { Do you think that the introduced instrument ful- } \\
\text { fils expectations and to what extent does it con- } \\
\text { tribute to more effective control and increased } \\
\text { voluntary tax compliance? }\end{array}$ & $\begin{array}{l}\text { giving an assessment of the institute is difficult } \\
\text { due to the short time it has been in force } \\
\text { higher expectations regarding the number of } \\
\text { taxpayers } \\
\text { improved control }\end{array}$ \\
\hline $\begin{array}{l}\text { How do you assess the suitability of the instru- } \\
\text { ment (the status for the promotion of voluntary } \\
\text { compliance) in light of the experience so far, in } \\
\text { particular in terms of any shortcomings, restri- } \\
\text { ctions and necessary changes to how this field is } \\
\text { currently regulated? }\end{array}$ & there is no need to change the legislation \\
\hline $\begin{array}{l}\text { Do you think that the inclusion of companies } \\
\text { in this instrument (the status for the promotion } \\
\text { of voluntary compliance) has contributed to } \\
\text { improving their internal tax controls and more } \\
\text { transparent co-operation with FURS in the sen- } \\
\text { se of providing information about any events } \\
\text { from which a company's tax liabilities could } \\
\text { arise? }\end{array}$ & yes, more or less \\
\hline
\end{tabular}

Source: own, 2016

FURS experts also provided some additional explanations that proved very useful for the study. On the subject of taxpayers, they explained that the pilot horizontal monitoring project included $1 \%$ of all taxpayers (large), who were paying between $50 \%$ and $60 \%$ of all taxes collected. With this, they wanted to stress the 
significance of the project and the subsequent enactment of the institute, pointing out that the institute is intended for taxpayers who wish to voluntarily fulfil their tax liabilities, which gives FURS the chance to spend its remaining resources more efficiently on those who do not wish to. The pilot project involved 18 taxpayers, with only 5 of them receiving the status under Article 99 of ZFU, while one application is currently in consideration. According to the experts, this disparity is the result of the fact that the pilot project was joined by many taxpayers who primarily expected advantages, in terms of a lower probability of ex-post controls or tax investigations and a resolution of tax uncertainty, while they themselves were not prepared to make any major changes. In the pilot project, the establishment of internal tax controls was not a prerequisite for participation, but they do need to be established for the acquisition of the status no later than within two years after the status is acquired. The respondents think that taxpayers with the status know that the latter means a great deal of additional work due to the establishment of internal tax controls and also believe that they operate in a transparent manner, are prepared to co-operate, view the examination of internal tax controls positively, take recommendations into account and implement them within the agreed time frames. The experts estimate that the inclusion of companies in the institute, i.e. the acquisition of the status, has contributed to the improvement of the internal tax controls of taxpayers, although it must be noted that the companies involved are exclusively the taxpayers of the Special Finance Office, which means that they were treated as "special taxpayers" in terms of the exchange of information relevant for taxation even before obtaining the status.

Furthermore, the experts emphasise that, in line with expectations, FURS began operating more in the sense of establishing partnerships with taxpayers (timely provision of information, explanations, personal contact with taxpayers, open communications, etc.) and less as a supervisory authority.

This pioneering attempt at a pilot approach to the introduction of an instrument that was launched by the then Tax Administration of the Republic of Slovenia (DURS), now known as FURS, was assessed by the experts as good and very useful since certain experience was gained, but the establishment of minimum tax standards (the requirement to establish a system of internal tax controls and the development of an appropriate methodology for verifying their functioning) as the objective of the pilot project was not achieved because the authority is understaffed.

The suitability of the instrument of the status for the promotion of voluntary compliance was assessed by the experts as appropriate, since ongoing control of taxpayers and their internal tax controls is indeed carried out, which is why there is no need for subsequent investigations, although they are legally possible. They 
did point out, however, that expectations regarding the number of taxpayers who would submit an application were higher, and that even with the current number of taxpayers involved the contact persons employed at FURS had to demonstrate significant commitment. Nevertheless, they highlighted two concrete proposals for improvement, specifically changing the conditions for gaining the status and changing the self-evaluation questionnaire on internal tax controls currently in use. In addition, the experts stress the role or importance of taxpayers' internal audit services which could carry out some of the tasks that are otherwise performed in the context of the special status, and the importance of proper insurance for liabilities, given the fact that even taxpayers with the status may be subject to subsequent investigations.

The second part of the study ("general questions for FURS") included the following questions:

1. Before deciding to introduce this instrument, did FURS or the Ministry of Finance conduct an analysis of the potential tax advantages for the country, taking into account the tax gap (the difference between the actual and the paid tax liabilities), which could be achieved by the introduction of this instrument?

2. Was there an evaluation of other potential long-term effects of the introduction of this instrument - organisational, staffing and other changes at FURS prior to the decision to introduce the horizontal monitoring instrument?

3. What activities is FURS currently performing in this field?

From the extensive answers of FURS, which mainly summarised the explanations of the institute published on FURS website and in the Proposal for the Financial Administration Act, we managed to determine the essence of the answers to our questions. As regards analysing the potential tax advantages for the country, the authority explained that although it would be possible to assess the indirect impact of co-operative compliance on reducing the tax gap, this would require financial and human resources and various external experts (behavioural economists, statisticians, etc.), which FURS does not have. Despite this and given the fact that the introduction of the institute in the Slovenian tax environment began at the end of 2015, FURS is planning to gather data and information to serve as the foundation in designing criteria and indicators to assess the efficiency and effectiveness of the activity with which the tax administration wants to improve the tax compliance of major companies and thereby protect society and financial interests (which is FURS' second strategic objective) by having more resources to spend on taxpayers who are not prepared to meet their obligations voluntarily. Data that it collects or intends to collect includes: 
- the number of applications for the special status and the number of statuses granted to taxpayers,

- assessment of the reliability of internal tax controls - the number and the types of identified shortcomings of internal tax controls,

- the number of recommendations issued,

- taxpayer satisfaction assessment - establishing trust in FURS (presumably once a year, at work meetings or using a questionnaire),

- the number of disputes (complaints processed) with taxpayers who were granted status compared to all large taxpayers,

- the number of work meetings, the number of disclosures of uncertain tax situations and the number of undisclosed situations identified during ex-post control,

- the number of explanations issued and the amount of binding information issued,

- the number and amounts of voluntary disclosures compared to the number and amounts of voluntary disclosures of all large taxpayers.

In regard to the second question (other potential long-term effects of the introduction of this instrument - organisational, staffing and other changes at FURS), FURS replied that the horizontal monitoring project was launched in 2010 and included 18 large companies. With this pilot project, FURS wanted to answer the question of whether it is appropriate in the Slovenian tax environment to establish such a system of monitoring of all taxpayers who wish to fulfil voluntarily their tax liabilities and are willing to disclose their risks and establish effective internal control systems for tax purposes. After a two-year co-operation with taxpayers, an analysis or assessment of the project's performance was carried out, which showed that the project was assessed positively ${ }^{2}$, and the decision was made to extend the pilot project, to solve the open issues in the meantime and to lay the groundwork for the inclusion of such forms of co-operation in legislation. In addition to assessing the satisfaction of taxpayers and employees with the pilot project of horizontal monitoring, FURS in February 2015 also carried out a survey among large companies to determine their familiarity with the possibility of being granted the special status and to measure their interest in submitting an application. Of the 61 submitted, FURS received 15 completed questionnaires, with 8 respondents answering that they are familiar with the development of the horizontal monitoring pilot project, 9 that they are familiar with Article 99 of ZFU, 8 said they are aware of the important advantages of the special status, and 11 were prepared to submit the application for the special status, though 3 of them would need additional information.

2 A survey was carried out among the employees who participated in the project, as well as among taxpayers (separately in the banking sector and in other companies). 
Regarding the third question (FURS' current activities), FURS answered very generally without listing any specific activities, from which we conclude that the question was not formulated properly.

\section{DISCUSSION}

Our empirical analysis has shown that the introduction of the voluntary tax compliance instrument in the Republic of Slovenia was enacted on the basis of a previously implemented pilot project of horizontal monitoring and is founded on the experience of other countries (especially the Netherlands). The pilot testing of an idea or instrument is an excellent model of preliminary assessment of the effects of tax legislation, though in this case, unfortunately, inadequate for a more comprehensive analysis. The objective of our subsequent analysis was to determine to what extent the instrument fulfilled the expectations of the legislator or FURS in the sense of encouraging taxpayers to calculate and pay taxes properly and on time and to better utilise the available human, financial and material resources of the authority. The answers provided by the surveyed experts showed that the introduction of the institute fulfilled the expectations of FURS, while the effectiveness of the institute (better utilisation of resources) is impossible to assess for at least two essential reasons. The first is the fact that not enough time has passed since the institute was introduced, and the second reason is that no measurable criteria for such an assessment have been set.

The successful implementation of such tax policies or related legislative measures that should ultimately ensure positive long-term outcomes and satisfy the public interest is possible only with a systemic approach by all stakeholders (cross-sectoral co-operation at all levels), a comprehensively formulated plan (material and non-material resources, organisational and procedural changes, suitable legislation that is also adapted in other areas intertwined with this) and with the commitment of political decision-makers, who must make such measures, which promise long-term and diverse applications in many areas, a priority. A comparison of how this area is regulated in individual countries (the Netherlands, France, Croatia) reveals that they used comparable approaches, seeing that the criteria and administrative procedures for entry, the system of ensuring the credibility of taxpayers' tax data (internal tax controls) and the principles and the objectives of procedures are extremely similar, with the exception of the French model, which stipulates verifying the accuracy of data indicated in tax returns for a period of three to nine months after the end of the tax period, while procedures in the other countries may include a period of several years (Čičin-Šain, 2016). Regardless of the minor differences in approach, the principle whereby taxpayers are not excluded from potential ex-post tax control by investigators despite having joined the special arrangement of voluntary tax compliance applies in all of the countries, 
except Croatia. This may be one of the more important reasons why taxpayers do not opt for this mechanism in greater numbers.

In regulating this extremely important area, all countries are considering ways to ensure protection of the public interest even though the very concept of public interest is often a highly intangible category and varies from country to country. This means that the need to introduce such mechanisms and their subsequent effects vary depending on country size, level of development, industry structure, company size, etc.

\section{CONCLUSION}

After analysing the main non-quantified objectives of FURS in introducing the status of voluntary tax compliance, we can make a general conclusion that the instrument fulfilled the expectations of the legislator or FURS. The respondents (experts) pointed out that the expectations (unofficial, we presume) regarding the number of taxpayers who would join were greater, but this is information that cannot be found in official documents or answers provided by FURS. Furthermore, no major shortcomings have been detected, whereby it needs to be pointed out (this was mentioned several times in the surveys) that not enough time has passed since the introduction of the instrument for a more thorough assessment. We were, unfortunately, unable to investigate what FURS' current concrete activities are, except that five taxpayers closely co-operating with FURS acquired the status. In this article, we therefore did not focus on issues such as how many of these taxpayers already have internal tax controls in place and how many are still setting them up, what exactly these internal tax controls mean and what quality standards they must meet, etc. As regards the potential long-term effects of the introduction of the voluntary tax compliance institute and more transparent co-operation of certain taxpayers with FURS, our study found that from FURS' perspective such co-operation with taxpayers would facilitate the allocation of the tax authority's existing resources and a more thorough tax control of the most risky taxpayers.

Taking into account theoretical assumptions, it follows from all of the findings that although the instrument fulfilled the declarative expectations, its effectiveness is difficult to clearly identify and evaluate. An additional problem is the inadequate definition of quantified objectives at the introduction of the instrument, as well as of suitable indicators, which prevents making an economic analysis of the instrument and an evaluation of its effects in other areas. In any event, consideration should be given to examining the economic efficiency and other aspects of this and all future instruments, as this would, on the one hand, reveal the potential long-term effects on public finances and, on the other hand, the effects on the organisation, management and planning of the tax authority's operations. 


\section{REFERENCES}

1. Andreoni, James, Erard Sander and Feinstein, Jonathan. 1998. Tax Compliance. Journal of Economic Literature 36(2): 818-860.

2. Bakker, Anuschka, and Sander Kloosterhof. 2010. Tax Risk Management. From Risk to Opportunity. Netherlands: IBFD.

3. Baruch, Yehuda, and Brooks C. Holtom. 2008. Survey response rate levels and trends in organizational research. Human Relations 61(8): 1139-1160.

4. Braithwaite, Valerie. 2003. Dancing with tax authorities: Motivational postures and non-compliant actions. In Taxing democracy. Understanding tax avoidance and tax evasion, 15-39. Edited by Valerie Braithwaite. Aldershot: Ashgate.

5. Dimitrijević, Marina. 2016. Tax Compliance as an Imperative in the Contemporary State. Teme-Časopis za Društvene Nauke 40(2): 679-691.

6. Čičin-Šain, Nevia. 2016. A New Approach of the Croatian Tax Administration towards Taxpayers Based on Cooperation Instead of Repression: A True Change in Attitude. Croatian and Comparative Public Administration 16(4): 847-866.

7. Hofmann, Eva, Erik Hoelzl and Erich Kirchler. 2008. Preconditions of Voluntary Tax Compliance: Knowledge and Evaluation of Taxation, Norms, Fairness, and Motivation to Cooperate. Zeitschrift Fur Psychologie, 216(4): 209-217. http://doi.org/10.1027/0044-3409.216.4.209 (accessed November $15,2016)$

8. James, Simon, and Christopher Nobes. 2000. The economics of taxation. Principles, Policy and Practice. Harlow, England: Pearson Education Limited.

9. Kirchler, Erich, Erik Hoelzl and Ingrid Wahl. 2008. Enforced versus voluntary tax compliance: The »slippery slope« framework. Journal of Economic Psychology 29(2): 210-225.

10. Kirchler, Erich, Cristoph Kogler and Stephan Muehlbacher. 2014. Cooperative tax compliance from deterrence to deference. Current Directions in Psychological Science 23(2): 87-92.

11. Kovač, Polonca. 2016. Inšpekcijski nadzor: razprave, sodna praksa in komentar zakona. Ljubljana: Uradni list RS.

12. Kovač, Polonca and György Gajduschek. 2015. Contemporary Governance Models and Practice in Central and Eastern Europe. Bratislava: NISPAcee Press.

13. May, J. Peter and Robert S. Wood. 2003. At the Regulatory Front Lines: Inspectors' Enforcement Styles and Regulatory Compliance. Journal of Public Administration Research and Theory 13(2): 117-139. 
14. OECD - Organization for Economic Co-operation and Development. 2008. Study into the Role of tax Intermediaries, Organization for Economic Co-operation and Development, Paris.

15. Pinsonneault, Alain, and Kenneth Kraemer. 1993. Survey Research Methodology in Management Information Systems: An Assessment. Journal of management information 10(2): 75-105.

16. Popović, Dejan. 1997. Nauka o porezima in poresko pravo. Beograd: Savremena administracija.

17. Posner, A. Eric. 2000. Law and Social Norms: The Case of Tax Compliance. Virginia Law Review: 1781-1819.

18. Sertić, Andreja. 2012. Horizontalni monitoring i njegova primjena u drugim državama. Porezni vjesnik 21(7-8): 53-62.

19. Simone Lisa De, Richard C. Sansing and Jeri K. Seidman. 2013. When are Enhanced Relationship Tax Compliance Programs Mutually Beneficial? The Accounting Review 88(6): 1971-1991.

20. Šinkovec, Darja. 2012. Practical Experiences in Implementing the Horizontal Monitoring Pilot Project in Slovenia. Tax Tribune 28: 172-175.

21. Torgler, Benno. 2003. To evade taxes or not to evade: that is the question. Journal of Socio-Economics 32: 283-302.

22. Verbič, Miroslav, Mitja Čok and Darja Šinkovec. 2014. Some evidence for implementing an enhanced relationship in Slovenia. Financial theory and practice 38(1): 61-80.

23. Tax Adiminstration Act - Zakon o Finančni upravi (Official Gazette of Republic of Slovenia, No. 25/14) 
doc. dr. sc. Tatjana Jovanović

Fakultet za upravu, Univerzitet u Ljubljani, Slovenija

Tatjana.Jovanovic@fu.uni-lj.si

\section{OCJENA DOBROVOLJNE POREZNE USKLAĐENOSTI U SLOVENIJI: IZ PERSPEKTIVE POREZNIH VLASTI}

Primljen: 17. kolovoza 2018.

Prihvaćen: 25. rujna 2018.

Prethodno priopćenje

\section{Sažetak}

Od 2015. godine pojedini porezni obveznici mogu podnijeti zahtjev za poseban status u cilju promicanja dobrovoljnog ispunjavanja obveza u Poreznoj upravi Republike Slovenije (FURS), nakon što je pilot projekt horizontalnog praćenja uspješno završen 2010. godine. Teorijska podloga takvog statusa leži u ideji kooperativne usklađenosti, koja se može opisati kao praćenje, predviđanje i sprječavanje problema u odnosu poreznih vlasti i poreznih obveznika. Svrha ovog odjeljka je analizirati instrument koji bi trebao uspostaviti suradnju temeljenu na transparentnosti, razumijevanju i međusobnom povjerenju poreznih obveznika $i$ poreznog tijela. Metodologija istraživanja usmjerena je na istraživanje među poreznim stručnjacima koji su sudjelovali u izradi nacrta zakona o provedbi odnosa suradnje kao i stručnjaka ovlaštenih za praćenje rada instituta. Glavni ciljevi studije bili su usredotočeni na identifikaciju trenutnih aktivnosti, procjenu očekivanja, nedostatke, ograničenja i potencijalne promjene u identifikaciji instrumenta i procjenu dugoročnih učinaka instituta.

Ključne riječi: dobrovoljno ispunjavanje poreznih obveza, porezni obveznik, porezna uprava, kooperativni odnos

JEL: M41 